\title{
Reframing platform power
}

\author{
José van Dijck
}

Utrecht University, Netherlands

\section{David Nieborg}

Department of Arts, Culture and Media, University of Toronto, Canada

\section{Thomas Poell}

New Media and Digital Culture, University of Amsterdam, Netherlands

Published on 30 Jun 2019 | DOI: 10.14763/2019.2.1414

\begin{abstract}
This article addresses the problem of platform power by probing current regulatory frameworks' basic assumptions about how tech firms operate in digital ecosystems. Platform power is generally assessed in terms of economic markets in which individual corporate actors harness technological innovations to compete fairly, thereby maximising consumer welfare. We propose three paradigmatic shifts in the conceptualisation of platform power. First, we suggest to expand the notion of consumer welfare to citizen wellbeing, hence addressing a broader scope of platform services' beneficiaries. Second, we recommend considering platform companies as part of an integrated platform ecosystem, acknowledging its interrelational, dynamic structure. And third, we shift attention from markets as level playing fields towards societal platform infrastructures where hierarchies and dependencies are built into their architecture. Reframing platform power may be a necessary condition for updating and integrating current regulatory regimes and policy proposals.
\end{abstract}

Keywords: Platform regulation, Platform infrastructures, Platform power, Antitrust regulation, Tech companies

\section{Article information}

Received: 13 Jan 2019 Reviewed: 28 May 2019 Published: 30 Jun 2019

Licence: Creative Commons Attribution 3.0 Germany

Competing interests: The author has declared that no competing interests exist that have influenced the text.

URL: http://policyreview.info/articles/analysis/reframing-platform-power

Citation: van Dijck, J. \& Nieborg, D. \& Poell, T. (2019). Reframing platform power. Internet Policy Review, 8(2). DOI: 10.14763/2019.2.1414

This paper is part of Transnational materialities, a special issue of Internet Policy Review guest-edited by José van Dijck and Bernhard Rieder. 


\section{INTRODUCTION}

In March 2019, the European Commission fined Google's parent company Alphabet Inc. 1.5 billion euro for antitrust violations in the online advertising market-the third fine in three years. In July 2018, European Commissioner Margrethe Vestager had levied a record fine of 4.3 billion euro on Google for breaching European competition rules by forcing cell phone manufacturers to pre-install a dozen of the firms' apps when using Android-Google's mobile operating system. And in 2016, the company was punished for unlawfully favouring Google Shopping services in the results of its own search engine. Commenting on the EU-Google decisions, several critics interpreted the rulings as (European) retaliations against a single (US) tech company for exerting undue market power over potential competitors entering the digital market. Others saw them as an encouraging signal for lawmakers to actively counter the market power of one dominant company, paving the regulatory pathway for further antitrust measures. In a radically transforming digital world fuelled by data and steered by platforms, European regulators and policymakers are rethinking their strategies towards digital markets in which platform power mostly rests with US firms (Crémer, de Montjoye, \& Schweitzer, 2019). Meanwhile, scholars, politicians and citizens increasingly wonder whether the available arsenal of national and supra-national regulatory tools (e.g., antitrust law, competition law, privacy law, etc) are sufficiently agile when it comes to redressing the powerful position of tech companies in the era of "digital dominance" (Moore \& Tambini, 2018).

This article addresses the problem of platform power by probing current regulatory frameworks' basic assumptions about how tech firms operate in digital ecosystems. Should platform power be assessed merely in terms of economic markets in which individual corporate actors harness technological innovations to compete fairly, thereby maximising consumer welfare? Or does platform power need to be reconceptualised in the face of emerging platform ecosystems on which citizens and societies have become dependent for their social and democratic wellbeing? Recently, a number of American and European legal scholars have argued the need for a broader set of concepts to help investigate how power gets accumulated or abused in online networked environments (Cohen, 2017; Daskalova, 2015; Kahn, 2018; Rahman, 2018). In line with these calls for antitrust-reform, we question the suitability of prevailing legal-economic concepts to capture undue accumulation of platform power. We argue that power concentration and asymmetry can only be remedied if we widen the scope of legal frameworks to include the sociotechnical and political-economic relations in which these frameworks are embedded.

Reframing platform power is a necessary precondition for the potential harmonisation of different regulatory regimes. We acknowledge such efforts to be profoundly political and ideological in nature, so we have to articulate the normative stance from which we undertake this conceptual challenge. Our perspective is motivated by the needs of European states struggling to adhere to principles of fairness in governance, public accountability, and democratic control while being encapsulated in platform ecosystems which technical architecture and economic dynamics are firmly grounded in American neoliberal, and to some extent, libertarian principles (Jin, 2015; Mansell, 2017; Smyrnaios, 2018). With that politicaleconomic perspective in mind, we will take the EU decisions to fine Google-Alphabet in 2016 and 2018 as a starting point to ask how Europe's regulatory scope can be broadened to address platform companies' societal-rather than just economic-power. 


\section{THE NEED FOR RECONCEPTUALISING PLATFORM POWER}

The notion of platform has never been well-defined, as platforms are recognised as having "features of firms and of markets, involving both production and exchange" (Coyle, 2018a, p. 51).1 Attesting to this abstruseness is the fact that the term platform is often used interchangeably with the companies that own and operate them. Indeed, some of these firms have long enjoyed a rather vague status as "connectors" in an amorphous online space that allowed them to successfully dodge lagging regulatory frameworks (Napoli \& Caplan, 2017).2 By virtue of their rapid global expansion, successful single platforms became the backbone of sizeable companies, which then diversified by operating numerous "multi-sided platforms" or MSPs (Tiwana, 2014). After a bonanza of new market entrants, a few rapidly growing firms were able to position their own services at crucial intersections of an emerging platform ecosystem.3 As digital markets evolved, worries about concentration of power and an oligopolistic market structure have grown proportionally. In the US and Europe, those worries are particularly (though not exclusively) levelled at Alphabet-Google, Amazon, Facebook, Apple, and Microsoft (GAFAM). The Big Five are regarded by many not just as individual companies engaged in mutual competition, but also as a "corporate platform elite" utilising "superplatforms" to control the gateways to digital markets (Ezrachi \& Stucke, 2016; Dolata \& Schrape, 2018; Srnicek, 2017).

The quintet's rapid ascendance triggered several questions: what makes the big tech companies different from conventional market players? What makes them powerful as individual platform companies and as a collective? With the emergence of a platform-and-data-driven ecosystem, a mixture of old currencies (attention and capital) and new ones (data and users) became paramount to developing a shared set of platform mechanisms to rule digital interactions and transactions. Beyond sheer size or capital accumulation, central to most concerns is a platform company's ability to cajole large data flows to the detriment of consumers in terms of pricing (an old worry), but increasingly also in terms of citizens' personal information as instruments for manipulation and as input for artificial intelligence and machine learning analysis (new worries). This holds true for single companies' power, but perhaps even more so for the powerdynamic and mechanisms they share as co-developers of the ecosystem's infrastructure. Arguably the chief mechanisms in this dynamic are datafication and commodification: the algorithmic governance of data flows and their transformation into business models based on the trade of (mostly free) services for (mostly user-generated) data (Graeff, 2017; Van Dijck, Poell, \& De Waal, 2018).

Platforms' ability to develop interoperable technical and economic standards and to control a set of platform mechanisms, combined with their potential to leverage network effects and global diffusion, have become crucial conditions for power accumulation (Nieborg \& Poell, 2018). This distinctive power raises people's concerns about 1) their potential to endlessly recombine and reuse data flows as input for algorithmic knowledge; 2) their ability to manage various gateway functions to steer online traffic; 3) their potential to exert control over relationships with "complementors", platform-dependent stakeholders such as advertisers, app developers, newspapers, gig workers, home sharers; 4) their capacity to govern connective infrastructures on which users are increasingly dependent for all their online activities; and 5) their potential to interfere with social and democratic functions in society. 
Evidently, worries about platform power extend beyond mere economic concerns, and pertain not just to markets but to society as a whole. Yet there is no single regulatory framework to address all of these concerns. The most relevant regulatory frameworks are consumer law, competition law, antitrust law, and privacy law-areas the EU authorities have been laudably active in. They commonly focus on consumer welfare, looking into ways in which single companies behave in specific markets; their aim is to ensure a level playing field that is in the best interest of consumers with regards to pricing, accessibility, and choice. Since new entities like platforms, users, data flows, and algorithms have entered legislative and regulatory discourse, they are often used complementary to, or interchangeably with, conventional concepts. However, the mounting complexity of digital societies necessitates to revisit regulatory frameworks' basic assumptions.

American and European legal scholars have begun to ask whether regulatory frameworks still "capture the realities of how dominant firms acquire and exercise power in the Internet economy” (Kahn, 2018, p. 122). Coyle (2018b, p. 12) contends we ought to abandon a traditional market definition in favour of a wider classification of platforms as social constructs. Framing the problem beyond competition law, Cohen (2017, p. 144) points at the extraordinary power of platforms to supply and organise digital infrastructures that control not just markets, but "reshape the conditions for economic exchange". By the same token, Ezrachi and Stucke (2016, p. 586) wonder whether a level playing field is at all possible in a world "where entry is possible, but expansion will likely be controlled by super-platforms". And arguing in favour of an expansive antitrust framework, Patterson (2017) contends such a perspective should not only be applied to prevent anticompetitive conduct from platform owners to the economic detriment of consumers, but may also be used to prevent societal harm in the form of forcing consumers to exchange personal information for free services. In line with this reasoning, Colaps (2018) favours a coordinated EU-approach that connects relevant competition analysis to the misuse of personal data in digital markets.

So how can we address legitimate concerns about power abuse and undue power concentration of platform companies if they reach beyond the current legislative and regulatory frameworks? Such investigation starts with some basic questions: where is platform power located, at whom is it levelled, how and by whom is it exercised? We think it is crucial to widen conventional legal probes to include political and sociotechnical perspectives. Therefore, we propose three paradigmatic shifts in the conceptualisation of platform power. First, we suggest to expand the notion of consumer welfare to citizen wellbeing, hence addressing a broader scope of platform services' beneficiaries. Second, we propose to regard single platform companies as part of an integrated platform ecosystem, acknowledging its inter-relational, dynamic structure. And third, we shift attention from markets as (ideally) level playing fields towards societal infrastructures, in which platforms introduce new hierarchies and dependencies. Each of these shifts will be elaborated in the next three sections.

\section{FROM CONSUMER WELFARE TO CITIZEN WELLBEING}

Since the 1970s, the foundations of antitrust legislation, competition and consumer law, both in the US and in Europe, have rested on notions of single companies operating in markets aimed at safeguarding consumer welfare; the phenomenon of companies operating multisided platforms (MSPs) has later been squeezed into this frame. The 2016 and 2018 fines levelled at AlphabetGoogle illustrate this. Google's Search product has been the economic heart of its activities from the very onset but the company has "branched out" into disparate sectors, ranging from video- 
sharing to health and from retail to education. As noted in our introduction, in 2016, EUregulators proved that Google systematically favours its own Shopping product in its Search rankings, at the disadvantage of consumer choice and to the detriment of small businesses who are increasingly dependent on the search engine. The accumulation of market power was found to be contingent on the company's ability to leverage economies of scale and scope by aggregating transactions among consumers and businesses, as well as by vertical integration of data flows and algorithmically-driven analysis across products and divisions (Barwise \& Watkins, 2018).

The 2018-verdict was different from the 2016 one in that it fined parent company Alphabet for effectively imposing its services upon device manufacturers. Alphabet was also found guilty of enticing manufacturers and telecom operators to offer Google Search by giving them a revenue share each time a Google ad is clicked on. Forced integration of various platform services, according to the regulator, prohibits fair competition and gives the company unfair advantages over other entrants in the market for apps. In response to the EU-verdict, Google's chief executive Sundar Pichai warned that the EU-decision may harm consumer welfare because app bundling optimises the user experience and facilitates innovation by third-party developers (Warren, 2018).

The two EU-verdicts both address Google's ability to control a vertically integrated system upstream and downstream, at the expense of consumers as buyers of products and services, i.e., phones with pre-installed apps or Google Shopping deals. In general, the verdicts intersect with consumers' short-term interest, as they aim at preventing discriminatory pricing and guaranteeing consumer choice; and they protect the interests of entrepreneurs, ensuring a level playing field for businesses large and small. A generous reading of the verdicts shows how the regulator keenly recognises that "pricing" is a dubious concept in an environment where most services are often free of charge and where data have become the prime currency. Indeed, the notion of datafication leads to an expansive conception of consumer interest where the potential combination of data flows from different services may be primarily aimed at personalisation and profiling to steer consumer behaviour (Crain, 2019). Implicitly, the verdicts also address a longterm broader concern: Alphabet's ability to integrate its own hardware, software, analytics, distribution, and marketing services allows them to collect, store, and process more data, which in turn provides enormous competitive advantages when entering new markets, using them against competitors who lack historical data. In capturing the constellation of digital markets, legislators and regulators are thus reinventing the notion of "consumers".

In addition to being consumers and producers, users are also citizens who for their democratic and civic duties have come to depend on services offered by platform companies. Google does not just offer search and shopping services but also gives access to information and news-crucial for making informed democratic decisions- and provides advertising platforms which are tightly interlinked with the company's other platforms. Of course, one may argue a citizen "consumes" news and information, and therefore, Google's News aggregator or YouTube is no different than its Shopping product. Yet the data-flow integration in the back-end of news content-distribution with advertising, search, and social networking invokes a whole new set of questions about consumer welfare (Nechushtai, 2018). Are news consumers the same as retail consumers? Can profiled information derived from shopping data be used to send political advertisements?

The notion of platform users as citizens takes us beyond the definition of individual recipients of services for another reason. Citizens can also take the shape of collectives or public 
bodies-think of classes of students or public school systems, which for their educational data processing have become increasingly dependent on platform companies. Google, for instance, sells Chromebooks that come installed not only with Google's familiar services (Search, Gmail, etc.) but also with a specific set of apps, such as Google Suite for Education; the latter allows schools to integrate educational software along with performance tracking and analytics, as well as various administrative functions. The possibilities for cross-linking data flows from various platforms are of course manifold. Should school children be considered "customers" or a vulnerable group of citizens whose educational environment warrants special protection? In light of the 2016 and 2018 verdicts, the question is whether the EU-regulator should treat educational platforms differently from other platforms.

For more than one reason, the notion of consumer welfare is inadequate to account for citizens' wellbeing (Kahn, 2018; Melamed \& Petit, 2018). While most regulatory regimes currently address short term concerns about a user's welfare in terms of discriminatory pricing or controlled access, they hardly tackle the potential long-term consequences in terms of privacy, surveillance, access to accurate information, or (social) profiling that may be detrimental to citizen's wellbeing. Of course, those concerns may well be addressed under various other regulatory frameworks, such as the European General Data Protection Regulation (GDPR), but the point is that citizens enact different roles simultaneously. You cannot bracket off the "consumer" from the "citizen", the "entrepreneur" from the "worker", or the "patient" from the "student" in an online environment. The type of power that digital platforms deploy affects people in various different roles, and such multi-variety should be relevant to lawmakers and regulators when rethinking the governance of digital societies (Suzor, 2018).

Regulators can take a cue from tech companies themselves who, since 2017, have started to acknowledge the concurrent roles of users as consumers, entrepreneurs, and citizens-prompted mostly by public outcry against their deficient policies in terms of content moderation. An example to instantiate this was provided in July and August 2018, when Apple removed four of Infowars podcasts from iTunes because its host, US conspiracy theorist Alex Jones, broke Apple's Terms of Service with regards to hate speech; Google shut down Infowars' popular YouTube channel; Amazon abandoned Jones' companies' product endorsements; and Facebook removed four Infowars pages for violating the social network's policies on invoking violence and hate speech. Other significant platform services quickly followed suit by denying Infowars access to its services or banning it from some of their crucial MSPs. This is relevant for two reasons: first, platform operators acknowledge their user's consumer value as much as their civic role; and second, although the companies acted as individual "custodians of the internet" (Gillespie, 2018), their concerted-even if not orchestrated-effort instantiates a cognisance of their collective responsibility for a proprietary ecosystem that has far-reaching societal influence.

So while companies "govern" platform societies by acknowledging their societal impact on citizens-cum-consumers, regulators have not yet adapted their "governance of platforms" by integrating their segmented frameworks; some regulatory frameworks exclusively address companies and consumers while others relate to societal sectors and citizens.

\section{FROM PLATFORM COMPANIES TO AN INTEGRATED PLATFORM ECOSYSTEM}

Shifting the focus, we can observe another restriction built into the fragmented regulatory 
frameworks that renders them out of sync with reality: their scope is often limited to single companies forming proprietary ecosystems, whereas in everyday practice, these company ecosystems are part of an integrated online environment where they can be distinguished to a degree, but cannot be separated from each other. In both EU verdicts, Alphabet-Google was fined for the vertical integration of its own platform services to the detriment of consumers and competitors, small and large. With regards to the 2016 case, some asked why Alphabet was fined for funnelling consumers to Google Shopping, while Amazon-the real elephant in the retail market-remained unscathed. Concerning the 2018 verdict, some wondered why the EU did not investigate Apple for their bundling strategy across hardware (iPhone), operating systems (iOS), app stores (iOS App Store), and a number of other services. Google CEO Pichai implicitly alluded to Apple when, in his response to the 2018 verdict, he said that the forced "unbundling" of apps may "upset the balance of the Android ecosystem", which would send "a troubling signal in favour of proprietary systems over open platforms" (Warren, 2018). Indeed, a similar case could be made against Amazon; Kahn (2018) convincingly argued how Amazon harnesses its dominance in e-commerce and cloud hosting to expand its own line of business ventures into an “everything store" (Stone, 2013). Or consider Facebook, which besides running the world's major social network service, operates a "family of apps" (Messenger, Instagram, and WhatsApp), each of which can be seen as a "platform instance" that is integrated into Facebook's wider data infrastructure (Nieborg \& Helmond, 2019).

Each of these tech giants run their own chain of multi-sided platforms operated by a single "platform company". What renders them powerful is their ability to steer data flows and use them as input for algorithmic profiling and ad-targeting across their own platforms. One common response to corporate platform ecosystems becoming monopolistic is to demand breakups or refuse mergers of large MSP-owners with too much power in one market. Such a market could be a conventional consumer market (e.g., online platforms for retail or urban transport) but also a new kind of platform market (e.g., social networking or app stores). Criticasters have called the merger of Instagram and WhatsApp with Facebook unjustifiable market concentration-partly because Facebook tends to dominate the new market of social networking to the detriment of its direct competitors (e.g., the now defunct Google Plus), but perhaps even more so because it concurrently performs a gatekeeping function to online news distribution and advertising services. Facebook's ownership of the Facebook app, Messenger, Instagram and WhatsApp raises concerns about the company's potential sway over public discourse. Evidently, the concern of single tech companies operating as competing platform company ecosystems that dominate markets is still valid, but the power to control access to the ecosystem as a whole may be more disconcerting.

Another concern pertains to concentration of platform power within an oligopoly of company ecosystems (Smyrnaios, 2018). One way to measure market dominance is to look at relative market share compared to competitors (e.g., Google has approximately 90\% of the search market in Europe, while Microsoft's Bing has 7\%). Google forms a duopoly with Facebook in online advertising and with Apple in app stores, while cloud computing is controlled by a triopoly (Amazon-Google-Microsoft). Assessments of oligopolies come in contrasting flavours. For instance, public policy scholar Diane Coyle concludes that dominance in specific platform markets comes in the form of "intense oligopolistic rivalry with one or at most two of the rest of the GAFAM group" (Coyle, 2018a, p. 8). She argues that each platform market segment is dominated by a different combination of one, two, or three of the Big Five players; they compete in some segments, yet collaborate in others. By contrast, Nicholas Petit (2016) refers to big tech firms as "moligopolists", contending that they are engaged in a process of vibrant oligopolistic competition, hence benefitting a healthy digital market because there will always be at least a 
few rivalrous competitors.

Regardless of these different assessments of the Big Five as a collective power house, we think the complexity of platform power cannot be understood exclusively in terms of monopolistic or oligopolistic domination by single company ecosystems. Instead, we propose to broaden the scope from single corporations operating MSPs to an integrated platform ecosystem that allows us to inspect how platforms are behaving in relation to each other, across markets, and across societal sectors (Van Dijck, 2013). Taking an integral approach to the platform ecosystem, one has to look simultaneously at ownership relations in terms of power over data flows, as well as at technical and organisational control over the ecosystem as a whole. What does that imply?

Ownership relations are typically the focus of political economy approaches that scrutinise acquisitions, mergers, buy-outs, and partnerships (Hardy, 2014; Mosco, 2009; Winseck, 2008). Besides platform companies owning and operating their own MSPs, power is also derived from their ability to funnel a wide variety of actors across economic sectors into their online services (Bamberger \& Lobel, 2017; Bechmann, 2013). Governance over data flows that are proprietary and invisible to regulators or users gives platform companies enormous power over the ecosystem as a whole. For instance, in December 2018, the New York Times revealed that for years, Facebook had systematically given access to private user profiles to selected other platforms, such as Microsoft's Bing search engine, Amazon, and Spotify's music stream service (Dance et al., 2018). And on the technical level, the interweaving of multiple data flows is operationalised through the extension of platform features and buttons into third party sites and apps, e.g., Facebook's like button or log-in feature (Helmond, 2015; Nieborg \& Helmond, 2019).

The complexity of ownership relations, governance, and technical interrelations leads to a dynamic that is all but inscrutable to outsiders. For instance, Facebook had a partnership with Uber that allowed users to order taxis through its Messenger app. By the same token, we can identify Google as a shareholder of Uber, and yet Google Maps recently severed its integration of the taxi-app to allow for its product to attract customers from Uber's competitors. 4 These examples all go to show: platform companies may be competitors in one segment, they are partners in others as they may channel users towards their own branded services via rival platforms. Facebook's apps Messenger and Instagram, for instance, are the most downloaded apps in Apple's iOS App Store and they are used as often as Apple's own native apps that offer similar functionality. Through an intricate dynamic of relational platform services, tech companies manage to govern an opaque and complex ecosystem in which connections are invisible to the public eye and hence largely beyond societal control. The invisibility of centralised data flow control stands in sharp contrast to the user's lack of control over their own generated data.

Analysing such relationships across platforms, companies, and markets could theoretically result in an intricate taxonomy of single platforms and their mutual (ownership, governance, technical) connections. However, such efforts may be at best momentary since platform constellations are transient and dynamic. To design effective regulation, we need to be more pragmatic and untangle patterns of dependency that tie platforms, end-users, and complementors together. Such patterns allow us to see how some platforms accrue unfair advantages from controlling specific nodes in the integrated platform ecosystem, through gatekeeping, lock in, cross-subsidizing or combining crucial data flows. The notion of an integrated platform ecosystem potentially widens the conceptual horizon from single company platform configurations operating in specific markets to an integrated environment where platforms operate across markets and societal sectors. On the surface all platforms look equal: 
they tend to leverage similar management strategies, such as network effects, strong brands, a reliance on habitual usage and a striving for seamless connectivity (Barwise \& Watkins, 2018, p. 43). But once we examine the platform ecosystem as an integrated environment, it appears remarkably hierarchical in its (self-)organisation. Platform interdependency, as we will argue below, hinges mostly on infrastructural nodes of power.

\section{FROM PLATFORM MARKETS TO SOCIETAL INFRASTRUCTURES}

When we say that some platforms have crucial "infrastructural" power in the ecosystem, this may invoke images of equivalents in the physical world, such as mainports, interstate highways, water management, or sewer systems (Frischmann, 2012). Living in a digital world equally requires physical infrastructures upon which the platform ecosystem has been built that allow societies to organise all kinds of activities online.5 There are several reasons to complement the concept of markets with the notion of infrastructures online. First, some platforms have carved out gatekeeping positions in the ecosystem that gives them enormous leverage over all kinds of economic transactions entrusted to them as intermediaries between users, complementors, and businesses. Second, the influence of some platforms goes way beyond markets, affecting entire societal sectors, democratic processes, online social traffic, and national institutions.

The first reason prompts a definition of the term "infrastructural" in relation to platforms. Building on earlier work by Plantin et al. (2018), we refer to infrastructural platform services to identify the integral ecosystem's "nodes" through which data flows are managed, processed, stored, and channelled, and upon which many other online services, complementors, and users have come to depend. In our earlier work, we have identified some seventy infrastructural services, including social networking services, search engines, app stores, advertising systems, retail networks, cloud services, pay systems, identification services, audio-visual platforms and more, that have infrastructural functions (Van Dijck, Poell, \& De Waal, 2018). It is important to note that "infrastructural" is not a property of one platform itself, but a corollary of a platform's deployment and function in the context of other platforms in a dynamic ecosystem. Infrastructural services may vary in form and function: for instance, cloud services are very different than social networking services, and advertising platforms are distinct from app stores, hence warranting different treatment by regulators. Following this logic, attribution of infrastructural power can hardly be limited to one company or one market, but needs to apply to how platforms operate in conjunction.

Let us return to the EU's verdicts in both Google cases, which treats all platforms equally as markets, whether it is "search" or "shopping". The question arises: what would warrant the qualification of "search" as an infrastructural platform? The fact that Google's search engine handles $90 \%$ of online queries in the European search market, on which many businesses depend for their online visibility, is an important indication of its huge social responsibility. But equally relevant is the fact that Google simultaneously operates AdSense and Google Marketing Platform (previously DoubleClick) as online advertising services upon which many users, including small businesses, depend. The combination of data flows allows for the potential interference of organic search results and paid (or sponsored) results. To ensure consumers' trust in its search engine, Google vows to keep them apart and to guarantee the neutrality of its search algorithms (Rieder \& Sire, 2014). Such promises are in a sense an acknowledgement of the platform's special (infrastructural) status, but whether they merit users' trust is problematic, 
considering Google’s proven misbehaviour in the 2016 Google Shopping case.

One condition for allowing a search platform to operate as a near-monopolist could be to regulate it as an infrastructural platform. Such epithet could warrant putting up a "firewall" around the platform because the neutrality or impartiality of algorithmic selection is crucial to its trustworthiness as a service across the integrated ecosystem. In the past, some legal scholars have proposed enforcing firewalls between different types of platforms, such as hardware producers, content creators, and distributors (Zittrain, 2008; Rahman, 2018). In our assessment, firewalling would affect individual platforms (e.g., Google Search) rather than an entire platform company or an entire class of platforms, for the succinct goal of guaranteeing a reliable infrastructure on which other platforms (including Alphabet's own) can rely. Acknowledgement of infrastructural platforms inevitably requires independent oversight to guarantee the transparency of a platform's use of algorithms and processing of data flows. Of course, such measures would deeply impact Alphabet's business models but it might be less drastic than other potential measures, including a forced breakup of the company. It is beyond our scope and expertise to explore specific regulatory instruments, but we will return to this in the conclusion.

The second motive to employ the notion of infrastructural is to highlight that some platforms have accrued considerable social and political value in addition to economic worth. In 2018, Facebook and Google both faced charges of political bias and manipulation pertaining to their social networks (Facebook and Instagram) and video sharing services (YouTube). The debate clearly reached a contentious stage, in which governments and citizens addressed platform companies as guardians of a societal infrastructure. During the 2018 parliamentary hearings in Brussels and Washington, where CEOs of the Big Five were called to testify, some politicians openly discussed whether draconian government interventions in a platform's operation (including forced break-ups) may be legitimate to guarantee the long-term sustainability of the connective ecosystem. It is a truism that politicians like to call for easy-to-understand, one-sizefits-all solutions. However, it is much harder to explain how differentiated services afford tech companies various types of power in the integrated platform ecosystem. Social networks and video-sharing platforms function differently from search engines, raising the question whether they should be regulated as media companies or publishing houses, holding them liable for content they distribute. Infrastructural services such as search engines could be regulated through neutrality requirements, but such measures work out very differently for social networking services which simultaneously function as news aggregators. As it stands now, platform companies with multiple MSPs are either exempted from regulation under section 230 (see note 2) or they face regulation under a single regulatory regime, likening them for instance to telecoms, software companies, internet service providers, or media companies. Based on a detailed analysis of particular platform services, as well as a nuanced understanding of the integrated platform ecosystem, we should be able to determine how these services function within the larger ecosystem. In turn, this should enable more precise regulation.

Besides the "how" of regulation, we should also address "who" is responsible. If we look at physical infrastructures, such as water management systems, it is commonly a government's responsibility to ensure facilities for water and sewage systems. As Cohen (2017, p. 144) observes, some physical infrastructures are managed as utilities by charging for metered consumption, others are privately managed but are subject to strict regulatory obligations. With regards to the integrated platform ecosystem, one may ask which pivotal platform functions controlled by corporate actors are no longer just optional infrastructures but hard-to-avoid necessities. To what extent should some infrastructural services be regulated as utilities while 
others can be provided as private services subject to regulatory control?

One problem we encounter here is that the idea of distinct public utilities, public sectors and public space is simply not part of the online ecosystem's architectural design. Institutions, governments, and non-governmental actors have rapidly integrated with, and become dependent on, the corporate platform ecosystem, where entire public sectors (e.g. health, education) are increasingly reliant on privately held infrastructural platforms (Lupton, 2016; Williamson, 2017). The mechanisms, strategies, and infrastructures developed by big tech companies are a contingent result of free-market forces; governments and non-market forces were never involved in their design. In other words, the integrated platform ecosystem imposes the market dynamics of online economic transactions and consumer behaviour on every type of online activity-economic or social, private or public-hence collecting and connecting data flows related to disparate practices, ranging from people's fitness regimes to democratic election processes. In a remarkable inversion of common hierarchies, societies historically imposing their administrative rules upon technological innovations have given way to a proprietary platform ecosystem that administers its data-and-algorithms-based rules upon societies (Caplan \& boyd, 2018).

While undergoing this seismic shift, citizens and policymakers have yet to recapture their public role vis-à-vis the platform ecosystem. How and where should non-corporate actors be involved in the ecosystem's organisation, particularly when infrastructural functions are at stake? Most relevant legal frameworks are still predicated on the notion that it is a government's task to take care of the public interest, while companies serve the private interest unless forced by governments to also take care of a public interest (Gerbrandy, 2016). If we would adhere to this principle, a simple conclusion would be that since there is no public infrastructure in the online world, its corporate players carry no responsibility for the common good. However, corporate actors find themselves increasingly confronted with societal backlashes, forcing them to accept the huge responsibilities that come along with organising not just the technical infrastructure for a consumer market but a societal apparatus defining the norms for human interaction and information exchange. Facebook's chief executive Mark Zuckerberg (2017) has openly admitted his social network service should now be considered a "social infrastructure".

The question as to whether or not to turn some platforms into utilities has been extensively discussed in legal circles.6 Eventually, though, platform governance is a political choice that needs to be decided at the various levels of policy-making. The safeguarding of public interest and public values has to come from local, national, or supra-national (EU) governments designing rules on how platform companies may run their services for the common good. In the best tradition of European democratic governance, responsibility for taking policy decisions may come from multi-stakeholder organisations balancing the interests of state, civil society, and market actors (Cowhey \& Aronson, 2017). So far, legal and regulatory authorities have typically acted cautiously within the bounds of distinctive legal frameworks to speak on behalf of consumers while applying market values; they have yet to find ways to account for public values or public interests where citizens are concerned-citizens whose interests go beyond typical consumer benefits and beyond typical market concerns. But if we accept the notion of an integrated platform ecosystem, we can only conclude that there is a desperate need for integrated policy and regulatory frameworks. 


\section{CONCLUSION: INTEGRATED ECOSYSTEMS REQUIRE INTEGRATED POLICY AND REGULATION}

The platformisation of products and services has not simply replaced old economies and markets, but it has profoundly transformed societal organisation and public accountability. We need to recognise the vital role the state and its citizens play in making markets serve society rather than the other way around; it is our contention that markets on their own will not provide a platform infrastructure that optimally serves society. In the previous sections, we proposed to reframe platform power by expanding the notions of consumers, companies, and markets to include broader notions of citizen wellbeing, an integral platform ecosystem, and societal infrastructure. Such expansive notions obviously push the envelope of current regulatory frameworks, but it may help pave the way for a comprehensive approach to policy-making and regulation. To get there, a few steps are necessary.

First, academics and policymakers need to deliver a more precise analysis and nuanced assessment of how the integrated ecosystem of platforms functions. Specific case studies may reveal how power is carved into the ecosystem's infrastructure, in its aggregation of data flows, and its algorithmic curation of online activities; how power is distributed amongst various stakeholders whose platforms exert distinctive yet interdependent functions in the ecosystem; how some of the services can be regarded as societal infrastructures and therefore warrant a regulatory treatment in kind with its public gravity; how the ecosystem facilitates competition and collaboration at the same time-integrating services from different platforms within the same company as well as from partnering and competing companies; and lastly, how such power is applied in the entire value chain, upstream and downstream, while acknowledging how various kinds of recipients may enact different roles simultaneously.

Such analyses can become more concrete when starting with an inquiry into selected areas of infrastructural power and conducting a fair number of such specific inquiries to help define relevant features. As Constantinides, Henfridsson, and Parker (2018, p. 396) propose, we might start with examining "whether social media should be viewed as 'critical infrastructure' given their ability to influence critical societal functions such as elections." Search engines could be a potential candidate for inquiry, considering their nodal function as information gateways. App stores could also be a vital object of scrutiny, given their intermediary positions as gatekeepers between end-users and (small) businesses, as well as their network-making power versus competitors. Besides social network sites, search engines, and app stores, we might want to look into online advertising and retail services as important gateways. But rather than examining them as single markets run by single proprietary ecosystems in the interests of consumers, it is essential to approach them as part of an integrated ecosystem inhabited by citizens who have become fully dependent on these systems for governing their personal and collective wellbeing.

Secondly, nuanced analyses of power in the integrated platform ecosystem can help articulate a cohesive set of governance principles, both at the EU-level as well as at national and local levels. New EU-reports evaluating approaches to platforms and data are beginning to show an awareness towards integrated societal interests (European Commission, 2018). A British discussion paper published by the IPPR Commission on Economic Justice forms a lightning example of what integrated policy-making at the national level could look like (Lawrence \& Laybourn-Langton, 2018). And at the local level, there is a growing awareness that cities and civil society organisations play a vital role in communal efforts to govern the platform society. Amsterdam and Barcelona, for example, are currently designing comprehensive platform 
policies that provide a basis for negotiating power with big platforms, such as Google and Airbnb, in urban areas where the control over data flows plays a vital role for urban infrastructures.

Thirdly, an analytic reframing of platform power could nourish efforts in various countries to harmonise, expand, and update current regulation. Harmonising single regulatory frameworks for antitrust, consumer, and competition law with recent updated frameworks that address privacy, media regulation, and net neutrality may be a first step towards an integrative approach. Regulators across Europe are cautiously exploring new territory, and it is encouraging that new policy directions are currently probed at various levels, national as well as transnational (Crémer, de Montjoye, \& Schweitzer, 2019). Policy studies and regulatory explorations that combine specific areas such as competition law and privacy law will bring the broader scope needed to penetrate the intricate and complex problem of platform power. Legal scholars have also called for a new range of potential (ex ante) measures besides the (ex post) levying of fines after proven legal violation. Gilman and Farrell (2018) courageously argue for the articulation of "moral frameworks" at the (supra-)national level-guidelines that help legislators and institutions navigate a world that is being remade by data, platforms, and algorithms.

At a time when governments are stepping up their antitrust efforts to curb Big Tech's power, we urge to look beyond single regulatory frameworks and consider the articulation of a comprehensive set of principles that can be applied to the platform ecosystem. We hope our reframing exercise may contribute to such integral perspective on regulatory regimes; if complemented by an analytical tool set that is both expansive and differentiated, we hope such effort supplies ammunition to both lawmakers' and regulators' efforts to govern the future platform society. 


\section{REFERENCES}

Bamberger, K.A., \& Lobel, O. (2017). Platform Market Power. Berkeley Technology Law Journal, 32(3), 2-41. doi:10.15779/Z38NooZT38

Barwise, T.P., \& Watkins, L. (2018). The evolution of digital dominance: how and why we got to GAFA. In M. Moore \& D. Tambini (Eds.), Digital Dominance: The Power of Google, Amazon, Facebook, and Apple (pp. 21-49). New York: Oxford University Press. Available at http://fdslive.oup.com/www.oup.com/academic/pdf/openaccess/9780190845124.pdf

Bechmann, A. (2013). Internet profiling: The economy of data intraoperability on Facebook and Google. MedieKultur, 55, 72-91. doi:10.7146/mediekultur.v29i55.8070

Caplan, R. \& boyd, d. (2018). Isomorphism through algorithms: Institutional dependencies in the case of Facebook. Big Data \& Society, 5(1). doi:10.1177/2053951718757253

Cohen, J. (2017). Law for the Platform Economy. UC Davis Law Review, 51(1), 133-204. Retrieved from https://lawreview.law.ucdavis.edu/issues/51/1/Symposium/51-1_Cohen.pdf

Colaps, A. (2018). Big Data: Is EU Competition Ripe Enough to Meet the Challenge? In R. Mastroianni \& A. Arena (Eds.), 60 Years of EU Competition Law. Stocktaking and Future Prospects (pp. 31-46). Napoli: Editoriale Scientifica.

Constantinides, P., Henfridsson, O., \& Parker, G.G. (2018). Introduction-Platforms and Infrastructures in the Digital Age. Information Systems Research, 29(2), 381-400.

doi:10.1287/isre.2018.0794

Cowhey, P.F., \& Aronson, J.D. (2017). Digital DNA. Disruption and the Challenges for Global Governance. New York: Oxford University Press.

Coyle, D. (2018a). Platform Dominance. The Shortcomings of Antitrust Policy. In M. Moore \& D. Tambini (Eds.), Digital Dominance: The Power of Google, Amazon, Facebook, and Apple (pp. 50-70). New York: Oxford University Press.

Coyle, D. (2018b). Practical Competition Policy Implications of Platforms [Working Paper No. 01/2018]. Cambridge: Cambridge University, Bennett Institute for Public Policy. Retrieved from https://www.bennettinstitute.cam.ac.uk/publications/practical-competition-policy-toolsdigital/

Crain, M. (2019). A critical political economy of web advertising history. In N. Brügger, N \& I. Milligan (Eds.), The SAGE Handbook of Web History (pp. 397-410). Los Angeles: SAGE.

Crémer, J., de Montjoye, Y-A., \& Schweitzer, H. (2019). Competition Policy for the Digital Era [Report]. Luxembourg: Publications Office of the European Union. Available at http://ec.europa.eu/competition/publications/reports/kdo419345enn.pdf

Dance, G.J.X., LaForgia, M., \& Confessore, N. (2018, December 18). As Facebook Raised a Privacy Wall, It Carved an Opening for Tech Giants. The New York Times https://www.nytimes.com/2018/12/18/technology/facebook-privacy.html

Daskalova, V. (2015). Consumer Welfare in EU Competition Law: What is It (Not) About? The Competition Law Review, 11(1), 131-160. 
Dolata, U.m \& Schrape, J-F. (2018). Collectivity and Power on the Internet. A Sociological Perspective. Cham: Springer. doi:10.1007/978-3-319-78414-4

European Commission. (2018). Artificial Intelligence. A European Perspective. Luxembourg: Publications Office of the European Union. doi:10.2760/11251

Ezrachi, A., \& Stucke, M.E. (2016). Virtual Competition. Editorial. Journal of European Competition Law \& Practice, 7(9), 585-586.

Frischmann, B.M. (2012). Infrastructure: the Social Value of Shared Resources. New York: Oxford University Press.

Gerbrandy, A. (2016). Toekomstbestendig Mededingingsrecht. Markt \& Mededinging, 3, 102-112.

Gillespie, T. (2010). The Politics of 'Platforms'. New Media \& Society, 12(3), 347-364. doi:10.1177/1461444809342738

Gillespie, T. (2018). Custodians of the Internet. New Haven: Yale University Press.

Gliman, N., \& Farrel, H. (2018, November 7). Three Moral Economies of Data. The American Interest. Retrieved from https://www.the-american-interest.com/2018/11/o7/three-moraleconomies-of-data/

Graeff, I. (2018). When Data Evolves into Market Power- Data Concentration and Data Abuse under Competition Law. In M. Moore \& D. Tambini (Eds.), Digital Dominance: The Power of Google, Amazon, Facebook, and Apple (pp. 72-97). New York: Oxford University Press.

Hardy, J. (2014). Critical political economy of the media: An introduction. New York: Routledge. doi:10.4324/9780203136225

Helmond, A. (2015). The Platformization of the Web: Making Web Data Platform Ready. Social Media \& Society, 1(2), doi:10.1177/2056305115603080

Jin, D.Y. (2015). Digital Platforms, Imperialism and Political Culture. New York: Routledge.

Kahn, L.M. (2018). Amazon- An Infrastructure Service and Its Challenge to Current Antitrust Law. In M. Moore \& D. Tambini (Eds.), Digital Dominance: The Power of Google, Amazon, Facebook, and Apple (pp. 98-129). New York: Oxford University Press. Available at http://fdslive.oup.com/www.oup.com/academic/pdf/openaccess/9780190845124.pdf

Lawrence, L., \& Laybourn-Langton, M. (2018). The Digital Commonwealth. From private enclosure to public benefit [Discussion paper]. London: IPPR Commission on Economic Justice. Retrieved from https://www.ippr.org/research/publications/the-digital-commonwealth

Lupton, D. (2016). The Quantified Self. London: Polity.

Mansell, R. (2017). Bits of Power: Struggling for Control of Information and Communication Networks. The Political Economy of Communication, 5(1), 2-29. Retrieved from http://www.polecom.org/index.php/polecom/article/view/75

Melamed, A., \& Petit, N. (2018). The Misguided Assault on the Consumer Welfare Standard in the Age of Platform Markets. Review of Industrial Organization, 54(4), 741-774. 
doi:10.1007/s11151-019-09688-4

Moore, M., \& Tambini, D. (Eds.), Digital Dominance: The Power of Google, Amazon, Facebook, and Apple. New York: Oxford University Press.

Mosco, V. (2009). The Political Economy of Communication (2nd ed.). Los Angeles: Sage.

Napoli, P. M., \& Caplan, R. (2017). Why media companies insist they are not media companies, why they're wrong, and why it matters. First Monday, 22(5). doi:10.5210/fm.v22i15.7051

Nechushtai, E. (2018). Could digital platforms capture the media through infrastructure? Journalism, 19(8), 1043-1058. doi:10.1177/1464884917725163

Nieborg, D. B., \& Poell, T. (2018). The platformization of cultural production: Theorizing the contingent cultural commodity. New Media \& Society, 2O(11), 4275-4292.

doi:10.1177/1461444818769694

Nieborg, D. B., \& Helmond, A. (2019). The Political Economy of Facebook's Platformization in the Mobile Ecosystem: Facebook Messenger as a platform instance. Media, Culture \& Society, 41(2), 196-218. doi:10.1177/0163443718818384

Pasquale, F. (2015). The Black Box Society: The Secret Algorithms That Control Money and Information. Cambridge: Harvard University Press

Patterson, M. R. (2017). Introduction. In Antitrust Law in the New Economy: Google, Yelp, LIBOR, and the Control of Information (pp. 1-20). Cambridge, MA: Harvard University Press. Retrieved from https://ssrn.com/abstract=2941573

Petit, N. (2016). Technology Giants, the Moligopoly Hypothesis and Holistic Competition: A Primer. doi:10.2139/ssrn.2856502

Plantin, J.-C., Lagoze, C., Edwards, P. N., \& Sandvig, C. (2018). Infrastructure studies meet platform studies in the age of Google and Facebook. New Media \& Society, 2O(1), 293-310. doi:10.1177/1461444816661553

Rahman, K. S. (2018). The New Utilities: Private Power, Social Infrastructure, and the Revival of the Public Utility Concept. Cardozo Law Review, 39(5), 1621-1689. Available at https://brooklynworks.brooklaw.edu/faculty/988/

Rieder, B., \& Sire, G. (2014). Conflicts of Interest and Incentives to Bias: A microeconomic critique of Google's tangled position on the Web. New Media \& Society, 16(2), 195-211. doi:10.1177/1461444813481195

Stone, B. (2013). The Everything Store: Jeff Bezos and the Age of Amazon. New York: Little, Brown and Company.

Smyrnaios, N. (2018). Internet Oligopoly: The Corporate Takeover of Our Digital World. Wagon Lane: Emerald.

Srnicek, N. (2017). Platform Capitalism. London: Polity.

Suzor, N. (2019, in press). Lawless: The secret rules that govern our digital lives. Cambridge: Cambridge University Press. 
Tiwana, A. (2014). Platform Ecosystems. Aligning Architecture, Governance, and Strategy. Amsterdam: Morgan Kaufmann.

Thierer, A. (2013). The Perils of Classifying Social Media Platforms as Public Utilities. Commonlaw Conspectus, 21(2), 249-297. Retrieved from https://scholarship.law.edu/commlaw/vol21/iss2/2/

Van Dijck, J. (2013). The Culture of Connectivity. A critical history of social media. New York: Oxford University Press.

Van Dijck, J., Poell, T., \& De Waal, M. (2018). The Platform Society. Public values in a connective world. New York: Oxford University Press.

Warren, T. (2018, July 18). Google warns Android might not remain free because of EU decision. The Verge. Retrieved from https://www.theverge.com/2018/7/18/17585396/googleandroid-eu-fine-response.

Williamson, B. (2017). Big Data in Education: The digital future of learning, policy and practice. London: Sage.

Winseck, D. (2008). The State of Media Ownership and Media Markets: Competition or Concentration and Why Should We Care? Sociology Compass, 2(1), 34-47. doi:10.1111/j.17519020.2007.00061.x

Zittrain, J. (2008). The Future of the Internet and How to Stop It. New Haven: Yale University Press. Available at http://yupnet.org/zittrain/

Zuckerberg, M. (2017). Building Global Community [Note]. Retrieved from Facebook website: https://www.facebook.com/notes/mark-zuckerberg/building-globalcommunity/101545442928066

\section{FOOTNOTES}

1. In the context of this article, we understand platforms as "(re-) programmable architectures designed to organize interactions among heterogeneous users that are geared toward the systematic collection, algorithmic processing, circulation, and monetization of data" (Van Dijck, Poell, \& De Waal, 2018, p. 4). For a more thorough definition of the various meanings of platforms, see Gillespie (2010).

2. For example, in the US, Facebook and Google operate with few restrictions thanks to section 230 of the 1996 Communications Decency Act releasing them from free speech liability.

3. For lack of a better term, we use the metaphor "ecosystem", but we are acutely aware of the restrictions involved in such figurative use; it is notoriously vague and shows a tendency to 'naturalise' social structures.

4. For a long time, one could order an Uber taxi from inside Google Maps; Google quietly took away this direct link in June 2018.

5. The term "infrastructure" may be confusing because there is a difference between what we call "digital infrastructure" and "platform infrastructure". We follow Constantinides, Henfridsson, and Parker in their definition of digital infrastructures as "the computing and network resources that allow multiple stakeholders to orchestrate their service and content needs” (2018, p. 381). 
Examples of digital infrastructures are the internet itself, data centres, and communication satellites. There is an increasingly gliding scale between digital and platform infrastructure; this is what Plantin et al. (2018) have theorised as the "infrastructuralization of platforms" and the "platformization of infrastructure". For example, cloud servers come disguised as platform services and are owned and operated by platform companies (e.g., Amazon Cloud Services).

6. There has been a fierce debate in media and scholarship whether some of the big companies should be touted utilities because their services have become common goods like water or electricity. Briefly summarised, the legal debate hoovers between two extremes: while some experts argue that demanding public service from corporate platforms or forcing private corporations to become "utilities" is not a legal option (Thierer, 2013), others have argued that a public utility frame "accepts the benefits of monopoly and chooses to instead limit how a monopoly may use its power” (Wu, 2010, p. 1643, cited in Kahn 2018, p. 120). 